\title{
Chitosan oligosaccharide addition affects current-year shoot of post- transplant Buddhist pine (Podocarpus macrophyllus) seedlings under contrasting photoperiods
}

\author{
Zi Wang ${ }^{(1)}$, \\ Yan Zhao (1), \\ Hongxu Wei ${ }^{(2)}$
}

\begin{abstract}
Chitosan oligosaccharides (COS) have been used as modifiers to promote growth and mineral nutrient utilization in crop plants, but its over-year effect on current-year shoot (CYS) of juvenile trees is still unclear. In this study, Buddhist pine (Podocarpus macrophyllus) seedlings were cultured under natural and extended photoperiods with or without COS addition for one year. In the following spring, parameters of leaf length, biomass accumulation, and $\mathrm{N}$ content in CYS were found to be increased by COS addition under the extended photoperiod. $\mathrm{P}$ concentration of COS-treated seedlings was lower under longer photoperiod, but both $\mathrm{N}$ and $\mathrm{P}$ concentrations were negatively correlated with leaf length and biomass accumulation, suggesting the utilization of $N$ and $P$ for growth demand of CYS. The sole addition of COS mainly resulted in wholeplant $\mathrm{P}$ accumulation. However, when combined with the extended photoperiod, COS addition showed over-year effect on biomass accumulation and $\mathrm{N}$ content in CYS of transplanted Buddhist pine seedlings. Further studies are needed to confirm these results on other tree species.
\end{abstract}

Keywords: Photoperiodism, Urban Afforestation, Yew Plum Pine, Marine Oligosaccharide, Fine Root

\section{Introduction}

During the past decade, there has been a worldwide increasing interest to explore new alternative enhancers of plant growth with low environmental impacts and lower adverse side effects on human health compared to current synthetic agrochemicals. In this context, chitosan is attracting more and more attention as a biodegradable natural polysaccharide derived from chitin through deacetylation. Chitin is an abundant and water insoluble biopolymer found mainly in the hard outer skeleton of marine animals (Jia et al. 2016). Chitosan is comprised of 2 -acetamido-2-deoxy- $\beta$-D-glucose (N-acetyl-D-glucosamine) and 2-amino-2-deoxy- $\beta$-D-glucan (D-glucosamine) attached via $\beta-(1,4)$ linkages. Chitosans include a wide group of molecules with a specific reactive amine group able to bind nega- tively charged molecules, e.g., proteins (Chatelain et al. 2013). Chitosan oligosaccharides (collectively oligochitosan or COS) are the enzymatic-hydrolyzed products of chitosan and can be used as plant growth regulators through seed coating (or seed dressing) and foliar spray (Chatelain et al. references therein). Most of the current knowledge on $\operatorname{COS}$ as plant modifiers was established according to studies on agricultural crops, while on woody species COS were mainly tested for biotic resistance (Hussain et al. 2012, Li \& Zhu 2013). So far, few studies have focused on the effect of COS addition on tree seedling growth. González et al. (2013) reported a promoting effect of seaweed-derived oligo-carrageenans on growth, cell division, basal metabolism, and carbon (C) and nitrogen ( $\mathrm{N}$ ) 2013, Wang et al. 2015, Jia et al. 2016 and
(1) College of Forestry, Henan University of Science and Technology, Luoyang 471003 (China); (2) Northeast Institute of Geography and Agricultural Ecology, Chinese Academy of Sciences, Changchun 130102 (China)

@ Hongxu Wei (weihongxu@iga.ac.cn)

Received: Dec 10, 2016 - Accepted: May 29, 2017

Citation: Wang Z, Zhao Y, Wei H (2017). Chitosan oligosaccharide addition affects currentyear shoot of post-transplant Buddhist pine (Podocarpus macrophyllus) seedlings under contrasting photoperiods. iForest 10: 715-721. - doi: 10.3832/ifor2302-010 [online 2017-0727]

Communicated by: Claudia Cocozza assimilations in 3-year-old Eucalyptus globulus trees. However, different sources of marine oligosaccharides may differently affect plant growth. As COS can modulate mineral uptake in crops (Chatelain et al. 2013), a favorable effect on growth and nutrition of tree species is expected.

Due to the low growing rate, culturing highly-valued tree seedlings in the nursery usually requires a long time before transplant to meet the quality standard. Extending the photoperiod by supplementing artificial illumination at night is an effective approach to cope with this issue (Garner \& Allard 1923, Watt \& McGregor 1963) and promotes a faster growth of slow-growing tree seedlings (Apostol et al. 2015, Riikonen et al. 2016). Recent studies mainly focused on the effect of extended photoperiod treatments in the nursery on growth and inherent nutrient status of slow-growing ornamental tree species (Wei et al. 2013, Zhu et al. 2016a, 2016b), though their overyear post-transplant performance has rarely been investigated.

Current-year shoot (CYS), including current-year buds, leaves, and twigs, is the most vulnerable tree organ (Gu et al. 2008, Augspurger 2009). It is also the main target (sink) of nutrient retranslocation from storing tissues in the spring (Nambiar \& Fife 1991, Millard \& Grelet 2010). Nitrogen (N) and phosphorus $(\mathrm{P})$ are two important nutrients whose previous-year uptake and overwinter storage may affect CYS growth in the next spring (Hawkins \& Henry 1999, Fernandez et al. 2007, Oliet et al. 2009, 
2011). Several studies have demonstrated the positive effect of previous nursery fertilization (e.g., exponential and late-season fertilization) on CYS growth in transplanted trees, which enhanced mineral storage and promoted nutrient retranslocation (Oliet et al. 2011, Wei et al. 2013, Pokharel \& Chang 2016). Recently, Wei et al. (2013) and Zhu et al. (2016a, 2016b) found that an extended photoperiod can promote growth and biomass accumulation in slow-growth tree seedlings, but resulted in the dilution of inherent $\mathrm{N}$ and $\mathrm{P}$ storage. According to Villar-Salvador et al. (2015), an extended photoperiod may also impact CYS growth of seedlings, due to the reduction of non-structural carbohydrates storage as a result of the prolonged photosynthesis. The above studies suggested the risk of unsatisfying CYS growth in transplanted seedlings reared under a longer photoperiod. To our knowledge, none of these hypotheses have been tested so far.

Podocarpus is a large plant genus comprising 97 species of evergreens and shrubs mostly found in the Southern Hemisphere. Buddhist pine (Podocarpus macrophyllus) is widely cultivated as a garden or landscape tree in sub-tropical areas of the northern hemisphere (Wei et al. 2013). In addition to the aesthetical character, Buddhist pine is also a valuable species for its pharmacological uses, though its cultivation is hampered by the low growing rate of seedlings. Recently, transplanted stocks of Buddhist pine seedlings cultured under extended photoperiod have been established as pre-trials in the Zijinshan Park $\left(34^{\circ}\right.$ $\left.45^{\prime} \mathrm{N}, 113^{\circ} 40^{\prime} \mathrm{E}\right)$, Zhengzhou City and in the Xiyuan Park ( $\left.34^{\circ} 39^{\prime} \mathrm{N}, 112^{\circ} 24^{\prime} \mathrm{E}\right)$, Luoyang City, Henan Province (China), with unsatisfying results. Therefore, a better understanding of the effect of photoperiod length on seedling quality is needed to enhance CYS growth in transplanted stocks.

The aim of this study was to compare growth and utilization of $\mathrm{N}$ and $\mathrm{P}$ in CYS of transplanted Buddhist pine seedlings cultured under contrasting photoperiods. COS was employed to test its potential interaction with photoperiod on influencing CYS growth. Our starting hypothesis was that growth and nutrient utilization in CYS were only promoted in seedlings treated with $\cos$ and reared under a longer photoperiod.

\section{Materials and methods}

\section{Seedling materials}

Buddhist pine seeds were collected from a seed orchard at Hangzhou, Zhejiang, China $\left(30^{\circ} 10^{\prime} \mathrm{N}, 120^{\circ} 20^{\prime} \mathrm{E}\right)$ by the East China Horticulture Garden (Shuyang, Jiangsu, China). On early April 2014, seeds were transported to the Laboratory of Urban Forests and Wetlands, Northeast Institute of Geography and Agricultural Ecology (Changchun, China), Chinese Academy of Sciences, and sterilized in potassium permanganate $(0.5 \%, \mathrm{w} / \mathrm{w})$ for $5 \mathrm{~min}$. Seeds were then soaked for $12 \mathrm{~h}$, half of them in distilled water and the other half were coated by soaking with a COS solution (Qishanbao ${ }^{\circledast}$, GlycoBio Co., Ltd., Dalian, Liaoning, China) at a concentration of $2 \mathrm{mg} \mathrm{kg}^{-1}$ $(w / w)$. Seeds were sowed in trays filled with sterilized sands for germination. On mid June 2014, germinated seeds were transferred to plug trays filled with mixed peat (Zhuangmiao ${ }^{\oplus}$ Peat Tech. Ltd., Changchun, Jilin, China) and perlite (3:1, v/v). Each trail included $32(4 \times 8)$ plugs of $7 \times 13 \mathrm{~cm}$ (diameter $\times$ height). Seedlings were cultured with a sub-irrigation system implemented for tree seedling culture (Bumgarner et al. 2015). Tanked water was maintained at the level of $4 \mathrm{~cm}$ in height by manual irrigation every day. The total number of seedlings cultured in this experiment was 1024.

\section{Photoperiod and marine}

oligosaccharide addition treatments

Photoperiod and COS treatments were applied to seedlings since one week after germinated seeds were planted. Plug trays were placed in two separated rooms (16 trays with 512 seedlings per room). In the first room, photoperiod was set at $18 \mathrm{~h}$ per day (from 6:00 a.m. to 24:00 p.m.) using 200-W plant grow lamps (Oudi ${ }^{\boxplus}$ Illumination Ltd., Huzhou, Zhejiang, China) which provided a photosynthetic photon flux density (PPFD) of $400 \mu \mathrm{mol} \mathrm{m} \mathrm{m}^{-2} \mathrm{~s}^{-1}$ at the apical tip of seedling shoots. In the other room, a "natural" photoperiod of $11.5 \mathrm{~h}$ per day (from 6:00 a.m. to 17:30 p.m.) with the same PPFD was provided to seedlings using the same lamps described above. A PPFD of $400 \mu \mathrm{mol} \mathrm{m}^{-2} \mathrm{~s}^{-1}$ was chosen because it was close to the light saturation point (LSP) of Podocarpus spp. (Fetene \& Feleke 2001, Seyoum et al. 2014). The natural photoperiod conditions were set based on data collected during pre-investigations carried out in the open air at Luoyang City (China), with available PPFD over light compensation point (LCP) of Buddhist pine $\left(\sim 20 \mu \mathrm{mol} \mathrm{m}^{-2} \mathrm{~s}^{-1}\right)$.

All seedlings were fed with fertilizers at the beginning of the treatments, according to the typical exponential fertilization model employed for Buddhist pine seedlings by Wei et al. (2013):

$$
N_{T}=N_{S}\left(e^{r t}-1\right)
$$

where $r$ is the relative addition rate required to increase $N_{S}$ to a final $\mathrm{N}$ content $\left(N_{T}+N_{S}\right)$ over the different fertilizer applications $(t=16) . N_{S}$ and $N_{T}$ are the initial $N$ content of seedlings and the desired amount to be added, which were set to $1.39 \mathrm{mg} \mathrm{N}^{\mathrm{N}}$ seedling ${ }^{-1}$ and $80 \mathrm{mg} \mathrm{N}^{\mathrm{N}}$ seedling ${ }^{-1}$, respectively. The quantity of fertilizer for each application $\left(N_{t}\right)$ was computed as follows (Wei et al. 2013):

$$
N_{t}=N_{S}\left(e^{r t}-1\right)-N_{t-1}
$$

where $N_{t-1}$ is the cumulative amount of $\mathrm{N}$ added up to the current application including all previous applications. The supplied fertilizer was Peters ${ }^{\circledR}$ Professional $\left(\mathrm{N}-\mathrm{P}_{2} \mathrm{O}_{5}\right.$ $\mathrm{K}_{2} \mathrm{O}, 20-20-20$, microelements added - Everris, CA Geldermalsen, Netherlands). At each fertilizer application, seedlings from COS-coated seeds were treated with exogenous COS through foliar spray, while the other seedlings were sprayed with the same volume of distilled water. All the described treatments were replicated in eight blocks. Plug trays in each room were shuffled every week to eliminate the possible edge effect. Average air temperature and relative humidity were kept at $24.9^{\circ} \mathrm{C}$ and $57 \%$, respectively, throughout the whole experiment.

In late October 2014, after the last application of fertilizers, the photoperiod was set at 11.5h (natural) for all seedlings in all rooms (including those previously subjected to extended photoperiod), the temperature was set at $10 / 16^{\circ} \mathrm{C}$ (night/day) and relative humidity at $36-43 \%$. These conditions are those commonly adopted in the Henan Province, in order to induce the formation of apical buds in Buddhist pine seedlings.

\section{Transplant experiment}

In late January 2015, seedlings were transplanted into plastic pots (top diameter $\times$ bottom diameter $\times$ height, $28 \times 20 \times 17 \mathrm{~cm}$ ) filled with soil collected from 60-year-old northeast black pine (Pinus tabuliformis var. mukdensis) plantations in the northern part of Nanhu Park, Changchun, Jilin, China $\left(43^{\circ} 51^{\prime} \mathrm{N}, 125^{\circ} 17^{\prime} \mathrm{E}\right)$. The soil was collected at the top $10 \mathrm{~cm}$ depth of the forest floor and determined for its properties, showing a texture of loamy with sand content at $\sim 60 \%$, bulk density of $1.42 \mathrm{~g} \mathrm{~cm}^{-3}, \mathrm{pH}$ of 6.22 , hydrolyzable $\mathrm{N}$ of $127.94 \mathrm{mg} \mathrm{kg}^{-1}$, available $\mathrm{P}$ of $18.40 \mathrm{mg} \mathrm{kg}^{-1}$, and organic matter of $3.5 \%$.

Four seedlings were transplanted in each pot, and a total of 128 plastic pots were used. Transplanted seedlings were watered according to real-time precipitations with temperatures controlled to mimic those in Zhengzhou, Henan, Central China (source data: Wunderground ${ }^{\oplus}$ - http:// www.wunderground.com).

\section{Seedling sampling and measurements}

Bud burst in treated seedlings began at DOY 50 (days of year, since Jan $1^{\text {st }}$ ). At DOY 105 (mid-April) current-year leaves had fully expanded in all seedlings, which were then all sampled the same day. Although some leaves turned to be dark green, dark yellow, or even brown, no apparent mortality was found. One of the four seedlings was randomly sampled in each plastic pot and four seedling samples were bulked as a single group in each combined treatment (photoperiod $\times$ COS) unit.

Seedlings were carefully hand-lifted from potted soils to maintain the whole root system intact. Excavated seedlings were carefully washed to clean soil residuals using 
tap water, then rinsed with distilled water and dried using tissue paper. Seedling height, root-collar diameter (RCD), and number of new roots (at least $2 \mathrm{~mm}$ in length, white and juvenile tips) were recorded. Thereafter, seedlings were divided into different organs: current-year shoots (CYS), past-year shoots (past-year leaves, twigs, and the stem), and roots. Top leaves of seedlings were greater than those at the stem base; therefore, leaf length was measured on three randomly-chosen leaves from the middle part of stem in both current-year and past-year shoots, and then averaged. The biomass of separated seedling organs was measured after oven-drying at $70{ }^{\circ} \mathrm{C}$ for $72 \mathrm{~h}$. Dried samples were ground to powder and determined for total $\mathrm{N}$ and $\mathrm{P}$ concentrations in the Laboratory of Forest Silviculture, Beihua University, Jilin, Jilin, China. A sample of $0.2 \mathrm{~g}$ dried powder was digested in $5 \mathrm{ml}$ of $\mathrm{H}_{2} \mathrm{O}_{2}$ $\mathrm{H}_{2} \mathrm{SO}_{4}$. The digestion solution was diluted to $50 \mathrm{ml}$. Seedling total $\mathrm{N}$ and $\mathrm{P}$ concentrations were determined using the Kjeldahl method and ICP-OES (Vista-MPX, Varian ${ }^{\circledR}$, USA), respectively.

\section{Statistical analysis}

Data were analyzed as a split-plot design with eight replicates to determine the effect of photoperiod (extended vs. natural), with or without COS addition, on morphology, biomass accumulation, and $\mathrm{N}$ and $\mathrm{P}$ contents in CYS and other organs. Photoperiod was taken as the main factor, while COS treatment was nested within the main factor. All the studied variables met the assumptions of homoscedasticity and normality, thus no data transformation was applied. Analysis of variation (ANOVA) was employed to analyze the effects using the "Proc GLM" program in SAS ${ }^{\oplus} 9.2$ (SAS Institute, Cary, NC, USA). All interactions were considered for all parameters in the analysis (Tab. 1). Differences were considered statistically significant when $p<0.05$. Relationships between nutrient concentrations and biomass or leaf length were analyzed by both Pearson's and Spearman's correlation analysis using the "Proc CORR". Where significance was detected, data were fitted to a suitable curve using SigmaPlot $^{\circledast}$ v. 12.0 (Systat Software, Inc., San José, CA, USA), and the relative coefficient of determination $\left(R^{2}\right)$ calculated.

\section{Results}

\section{Seedling morphology and biomass accumulation}

A significant interactive effect of beforetransplant photoperiod and $\operatorname{COS}$ addition was detected on RCD $(P=0.0349)$ and leaf length of CYS $(P<0.0001)$. Compared to seedlings grown under the extended photoperiod, RCD declined by about $13 \%$ in those receiving COS under the natural photoperiod (Fig. 1a). Mean leaf length in CYS was greatest in seedlings treated with $\mathrm{COS}$ under the extended photoperiod, exceed-
Tab. 1 - $F$ values from ANOVA testing the effect of $\mathrm{COS}$ addition (O), photoperiod (Ph), and their interaction $(\mathrm{O} \times \mathrm{Ph})$ on seedling parameters of growth, biomass accumulation, and $\mathrm{N}$ and $\mathrm{P}$ concentrations and contents in post-transplant Buddhist pine (Podocarpus macrophyllus) seedlings. (RCD): root collar diameter; (NNR): number of new roots; ( $L C Y L)$ : length of current-year leaves; (LPYL): length of past-year leaves; (*): $P<0.05 ;(* *): P<0.01 ;(* *): P<0.001$.

\begin{tabular}{llccccc}
\hline $\begin{array}{l}\text { Seedling } \\
\text { parameters }\end{array}$ & $\begin{array}{l}\text { Source of } \\
\text { variation }\end{array}$ & Height & RCD & NNR & LCYL & LPYL \\
\hline Growth & $\mathrm{O}$ & 1.52 & 0.92 & 2.72 & $15.98^{* * *}$ & 0.15 \\
& $\mathrm{Ph}$ & $9.24^{* *}$ & $11.40^{* *}$ & $8.29^{* *}$ & $44.73^{* * *}$ & $39.00^{* * *}$ \\
& $\mathrm{O}$ & 1.18 & $4.92^{*}$ & 0.03 & $32.36^{* * *}$ & 3.68 \\
\hline & - & New shoot & Old shoot & Shoot & Root & \\
\hline $\mathrm{N}$ & $\mathrm{O}$ & 0.66 & 1.13 & $25.20^{* * *}$ & $8.22^{* *}$ & \\
concentration & $\mathrm{Ph}$ & 0.74 & 1.93 & $25.42^{* * *}$ & $6.88^{*}$ & \\
& $\mathrm{O}$ & 3.05 & 0.87 & $5.79^{*}$ & 0.08 & \\
$\mathrm{P}$ & $\mathrm{O}$ & 0.01 & $4.54^{*}$ & $10.52^{* *}$ & 0.23 & \\
concentration & $\mathrm{Ph}$ & $11.41^{* *}$ & 0.81 & $10.68^{* *}$ & $6.84^{*}$ & \\
& $\mathrm{O}$ & $4.39^{*}$ & 2.26 & $4.73^{*}$ & 0.47 & \\
Biomass & $\mathrm{O}$ & $7.51^{*} \neq$ & 1.79 & $5.96^{*}$ & $5.08^{*}$ & \\
accumulation & $\mathrm{Ph}$ & $24.33^{* * *}$ & $31.28^{* * *}$ & $60.06^{* * *}$ & $36.72^{* * *}$ & \\
& $\mathrm{O}$ & $12.57^{* *}$ & $4.92^{*}$ & $8.78^{* *}$ & $5.05^{*}$ & \\
N content & $\mathrm{O}$ & $19.44^{* * *}$ & $51.98^{* * *}$ & $74.09^{* * *}$ & $22.24^{* * *}$ & \\
& $\mathrm{Ph}$ & 2.54 & $5.16^{*}$ & $7.86^{* *}$ & $8.06^{* *}$ & \\
& $\mathrm{O}$ & $4.70^{*}$ & 1.93 & $5.06^{*}$ & $5.19^{*}$ & \\
P content & $\mathrm{O}$ & $9.72^{* *}$ & $57.09^{* * *}$ & $36.74^{* * * *}$ & $22.79^{* * *}$ & \\
& $\mathrm{Ph}$ & 1.54 & 1.82 & 0.14 & $7.00^{*}$ & \\
& $\mathrm{O}$ & 0.2 & 0.06 & 0.06 & 1.11 & \\
\hline
\end{tabular}

ing by $50-80 \%$ that observed in other treatments (Fig. 1b). Photoperiod had a significant effect on seedling height $(P=0.0051)$, number of new roots $(P=0.0076)$, and length of past-year leaves $(P<0.0001)$, which were greater in the extended photoperiod by $17 \%, 35 \%$, and $40 \%$ than those in the natural one, respectively (Tab. 2).

Biomass was greatest in seedlings with $\mathrm{N}$ and $\mathrm{P}$ concentrations

COS addition under the extended photope- Treatments of photoperiod and COS addiriod for both CYS $(P=0.0014)$ and root tion had a significantly interactive effect on
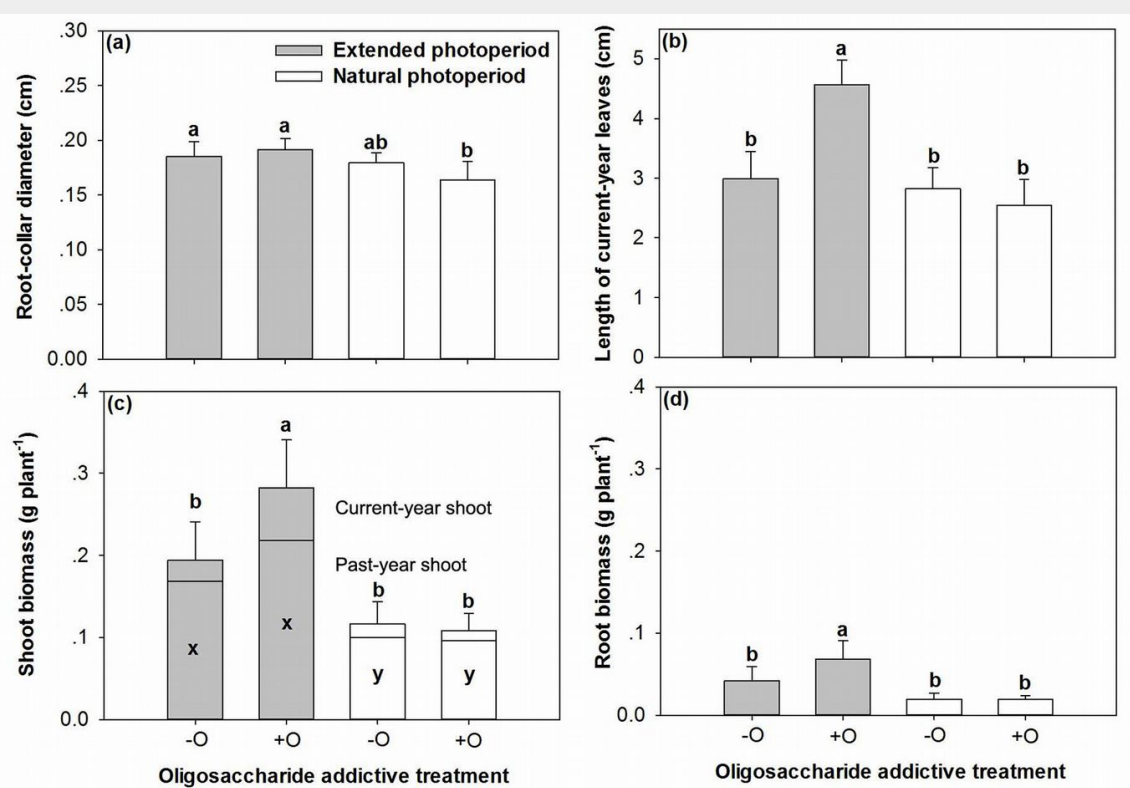

Oligosaccharide addictive treatment
Fig. 1 - (a) Root-collar diameter (RCD), (b) length of current-year leaves, and biomass accumulation in shoots (c) and roots (d) of post-transplanted Buddhist pine (Podocarpus macrophyllus) seedlings in response to before-transplant photoperiod treatment (extended vs. natural) with $(+O)$ or without $(-O) \mathrm{COS}$ addition. Different letters indicate significant differences $(p<0.05, n=8)$. In (c), a and $b$ for current-year shoot, while $x$ and $y$ for past-year shoot. 
Tab. 2 - Average seedling height, number of new roots, length of past-year needles, $N$ and $\mathrm{P}$ concentrations in root, past-year shoot $\mathrm{N}$ content, and root $\mathrm{P}$ content $( \pm$ standard error) in post-transplant Buddhist pine (Podocarpus macrophyllus) seedlings cultured under extended and natural photoperiods $(n=16)$. Different letters in the same row indicate significant differences $(\mathrm{p}<0.05)$.

\begin{tabular}{lcr}
\hline \multirow{2}{*}{ Parameters } & \multicolumn{2}{c}{ Photoperiod } \\
\cline { 2 - 3 } & \multicolumn{1}{c}{ Extended } & Natural \\
\hline Seedling height $(\mathrm{cm})$ & $7.08 \pm 1.02^{\mathrm{a}}$ & $6.05 \pm 0.62^{\mathrm{b}}$ \\
Number of new roots & $21.31 \pm 4.87^{\mathrm{a}}$ & $15.75 \pm 4.76^{\mathrm{b}}$ \\
Length of past-year leaves $(\mathrm{cm})$ & $3.93 \pm 0.54^{\mathrm{a}}$ & $2.81 \pm 0.34^{\mathrm{b}}$ \\
$\mathrm{N}$ concentration in root $\left(\mathrm{mg} \mathrm{g}^{-1}\right)$ & $21.02 \pm 3.38^{\mathrm{a}}$ & $16.88 \pm 5.00^{\mathrm{b}}$ \\
$\mathrm{P}$ concentration in root $\left(\mathrm{mg} \mathrm{g}^{-1}\right)$ & $0.83 \pm 0.28^{\mathrm{b}}$ & $2.06 \pm 1.58^{\mathrm{a}}$ \\
$\mathrm{N}$ content in past-year shoot $(\mathrm{mg})$ & $3.94 \pm 1.55^{\mathrm{a}}$ & $3.21 \pm 1.03^{\mathrm{b}}$ \\
P content in root $(\mu \mathrm{g})$ & $33.66 \pm 16.98^{\mathrm{b}}$ & $56.94 \pm 36.54^{\mathrm{a}}$ \\
\hline
\end{tabular}

Tab. 3 - Average $\mathrm{N}$ and $\mathrm{P}$ concentrations and contents in different organs ( \pm standard error) in post-transplant Buddhist pine (Podocarpus macrophyllus) seedlings cultured with or without $\operatorname{COS}$ addition $(n=16)$. Different letters in the same row indicate significant differences $(p<0.05)$.

\begin{tabular}{|c|c|c|}
\hline \multirow{2}{*}{ Parameters } & \multicolumn{2}{|c|}{ COS addition } \\
\hline & With COS & Without COS \\
\hline $\mathrm{N}$ concentration in roots $\left(\mathrm{mg} \mathrm{g}^{-1}\right)$ & $16.69 \pm 2.92^{b}$ & $21.21 \pm 5.16^{a}$ \\
\hline $\mathrm{N}$ content in past-year shoots $(\mathrm{mg})$ & $4.74 \pm 1.07^{\mathrm{a}}$ & $2.41 \pm 0.57^{\mathrm{b}}$ \\
\hline $\mathrm{P}$ concentration in past-year shoots $\left(\mathrm{mg} \mathrm{g}^{-1}\right)$ & $0.56 \pm 0.12^{a}$ & $0.45 \pm 0.15^{b}$ \\
\hline P content in current-year shoots $(\mu \mathrm{g})$ & $74.93 \pm 49.85^{\mathrm{a}}$ & $28.40 \pm 13.87^{b}$ \\
\hline P content in past-year shoots $(\mu \mathrm{g})$ & $106.69 \pm 25.57^{\mathrm{a}}$ & $41.83 \pm 15.36^{b}$ \\
\hline P content in shoots $(\mu \mathrm{g})$ & $181.62 \pm 58.60^{a}$ & $70.22 \pm 20.39^{b}$ \\
\hline $\mathrm{P}$ content in roots $(\mu \mathrm{g})$ & $66.30 \pm 31.44^{\mathrm{a}}$ & $24.30 \pm 11.90^{b}$ \\
\hline
\end{tabular}

$\mathrm{N}$ concentration in shoot $(P=0.0230)$ and $\mathrm{P}$ concentrations were highest in seedlings concentration in both shoot $(P=0.0382)$ receiving $\operatorname{COS}$ addition under the natural and CYS ( $P=0.0453$ - Tab. 1). Both $\mathrm{N}$ and $\mathrm{P}$ photoperiod (Fig. 2A, Fig. 2B), and $\mathrm{P}$ con- centration in CYS for this treatment was only higher than that in seedlings receiving $\mathrm{COS}$ addition under the extended photoperiod (Fig. 2C). Moreover, photoperiod had a significant effect on both $\mathrm{N}$ and $\mathrm{P}$ concentrations in roots, which had higher $\mathrm{N}$ by $25 \% \quad(P=0.0139)$ but lower $P$ by $60 \%$ $(P=0.0142)$ in the longer photoperiod (Tab. 2). In contrast, the addition of COS decreased $\mathrm{N}$ concentration in root by $27 \%$ $(P=0.0078)$, but this treatment increased $P$ concentration in past-year shoot by $25 \%$ $(P=0.0421)$.

\section{$N$ and $P$ contents}

The responses of $\mathrm{N}$ content in CYS and root to combined treatments were similar to those observed for biomass $(P=0.0387$ and $P=0.0305$, respectively - Fig. 3 ), but $N$ content in CYS of seedlings receiving COS was not different between the two photoperiods (Fig. 3a). Instead, photoperiod had a significant effect on $\mathrm{N}$ content in past-year shoot $(P=0.0301)$ and $P$ content in root $(P=0.0132)$, which were higher by $23 \%$ but lower by $41 \%$ in seedlings cultured under extended photoperiod, respectively, compared with those reared under normal photoperiod (Tab. 2). The addition of COS increased not only $\mathrm{N}$ content in past-year shoots $(P<0.0001)$, but also $P$ content in all seedling organs (Tab. 3).

\section{Correlation analysis}

Both Pearson's and Spearman's correlation analyses were conducted between $\mathrm{N}$
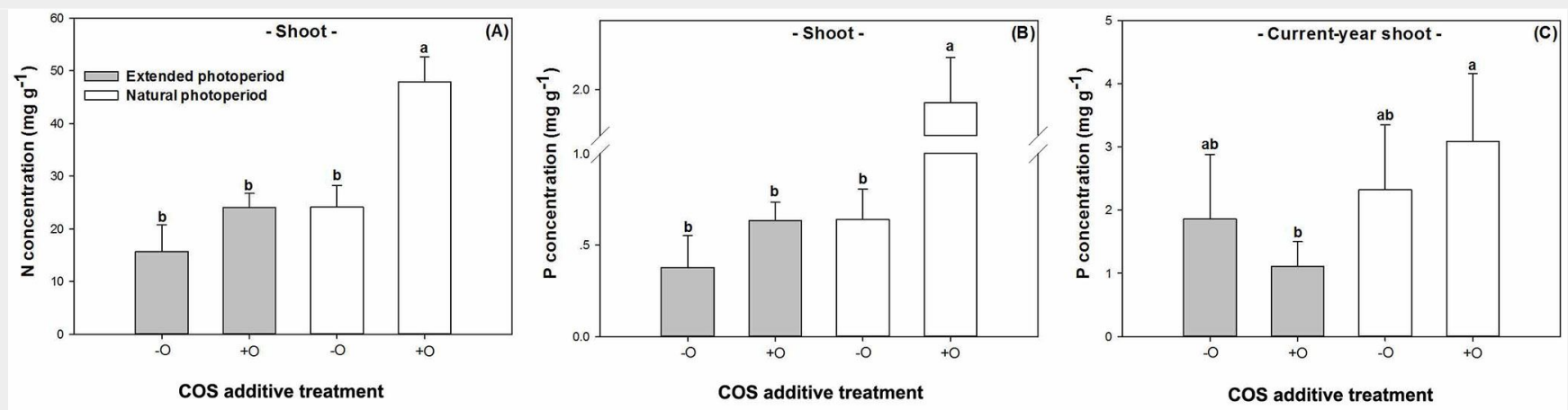

Fig. 2 - (A) Nitrogen (N) and (B) phosphorus (P) concentrations in shoots and P concentration in current-year shoots (C) of posttransplanted Buddhist pine (Podocarpus macrophyllus) seedlings in response to before-transplant photoperiod treatment (extended vs. natural) with $(+O)$ or without $(-0) \operatorname{COS}$ addition. Different letters indicate significant differences $(p<0.05, n=8)$.

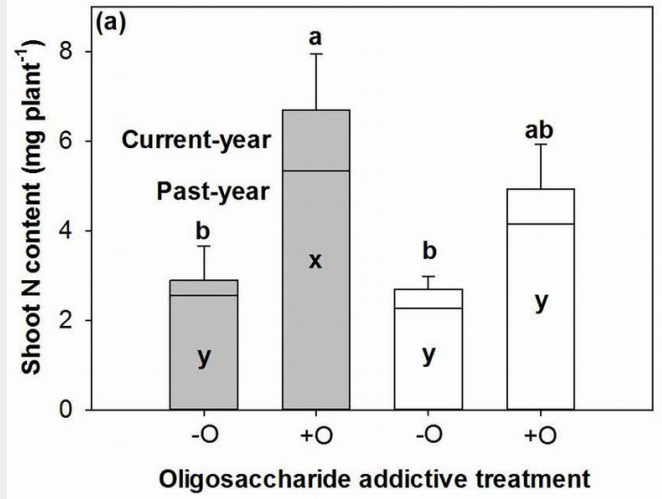

Oligosaccharide addictive treatment

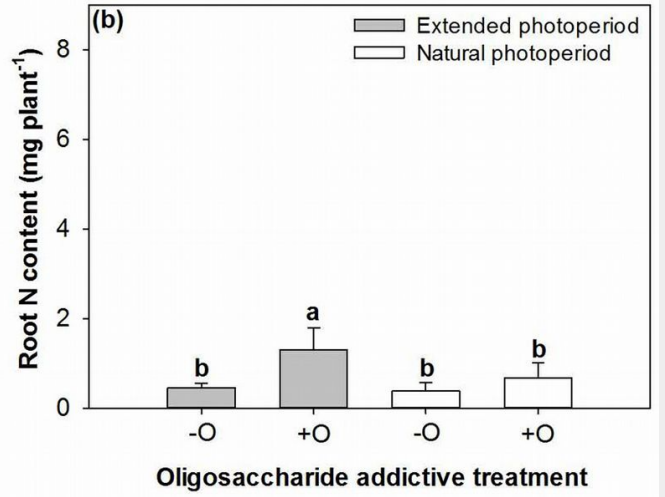

Fig. 3 - Nitrogen $(\mathrm{N})$ content in shoot (a) and root (b) of post-transplanted Buddhist pine (Podocarpus macrophyllus) seedlings in response to before-transplant photoperiod treatment (extended vs. natural) with $(+O)$ or without (-O) COS addition. Different letters indicate significant differences $(p<0.05$, $n=8$ ). In (a), a and b for current-year shoot, while $x$ and y for past-year shoot. 
Fig. 4 - Regression analysis of biomass or foliar length in CYS using $(A)$ nitrogen $(\mathrm{N})$ and $(\mathrm{B})$ phosphorus $(\mathrm{P})$ concentrations as predictors in post-transplanted Buddhist pine (Podocarpus macrophyllus) seedlings.
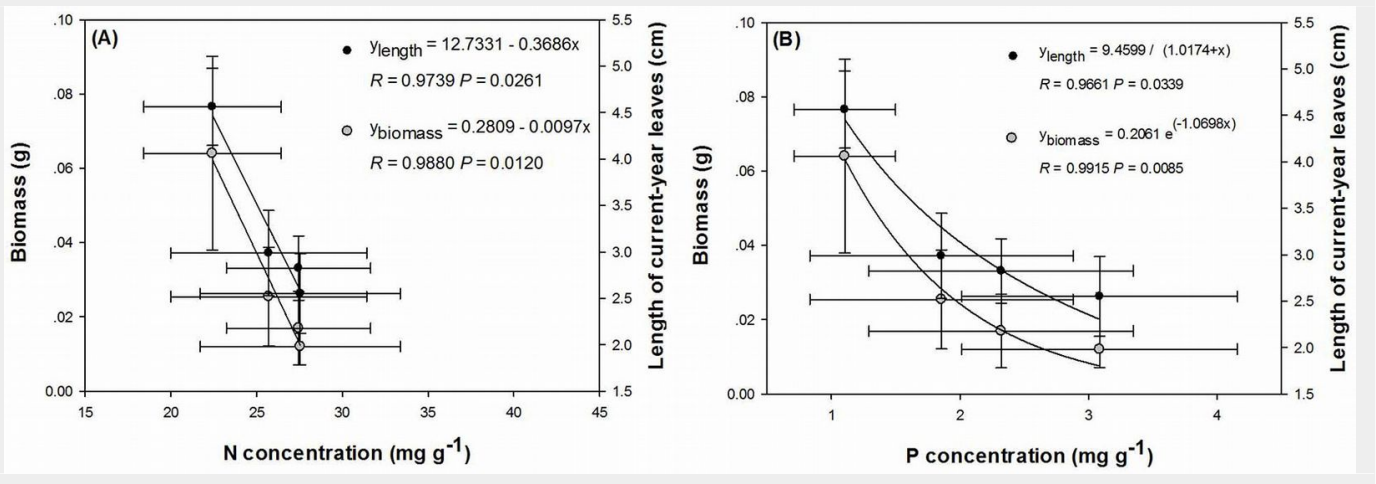

and $\mathrm{P}$ concentrations and biomass and growth parameters. In CYS, $\mathrm{N}$ concentration had a negative relationship with both biomass ( $R=-0.9865, P=0.0135)$ and leaf length $(R=-0.9739, P=0.0261)$ according to the Pearson's correlation, while $\mathrm{P}$ concentration had a negative relationship with both parameters according to the Spearman's correlation $(P<0.0001$ in both cases).

Regression analysis revealed that the relationships between $\mathrm{N}$ concentration vs. biomass and leaf length in CYS were best described by linear models (Fig. 4A), while the prediction of $\mathrm{P}$ concentration in seedling CYS using either parameters as independent variables were found to follow an exponential-decay model (Fig. 4B).

\section{Discussion}

Previous studies revealed that photoperiod does not affect root-collar diameter (RCD) in Buddhist pine seedlings (Wei et al. 2013, Zhu et al. 2016a, 2016b). Accordingly, our results showed an increase in $R C D$ under the extended photoperiod only with COS addition, which had no effect on seedling height. These findings contradict to those in González et al. (2013) and Dzung et al. (2011), wherein COS increased the growth of aerial tree parts. However, our results concur with those by Kollárová et al. (2012) on mung bean (Vigna radiate [L.] Wilczek) seedlings.

In our study, over $85 \%$ of seedling height was due to the first year stem growth, and mean height increased in seedlings subjected to extended photoperiod. An enhanced height growth induced by a longer photoperiod was also reported in Buddhist pine and Japanese maple (Acer palmatum) by other studies (Wei et al. 2013, Zhu et al. 2016b). Moreover, we observed a greater number of new roots in seedlings cultured under the extended photoperiod. This was in contrast to Zhu et al. (2016b), where seedlings were checked during the first year of culture and new roots competed with shoots for source utilization. Nonetheless, we observed new root production also in transplanted seedlings, where the effect of a longer photoperiod results in a larger storage of resources which are readily available for growth in the next spring. According to Villar-Salvador et al. (2015), conifers strongly rely on current photosyn- thesis and partly on $\mathrm{N}$ supply for early new root growth. This suggested that photoperiod might affect new root egression through the effect on current photosynthesis, though deeper studies are needed to elucidate the specific mechanism.

Leaf area affects plant productivity by increasing sunlight interception (Barigah et al. 1994). Leaf area of a coniferous tree mostly depends on needle elongation, and leaves usually grew rapidly in length at the beginning of the growing season (Silkina \& Vinokurova 2009). In our study, COS addition increased leaf length under extended photoperiod, and these results are consistent with those on biomass accumulation in all organs (Fig. 1C). This suggests that $\cos$ may have enhanced photosynthesis rate by increasing current leaf length in seedlings grown under extended photoperiod, thus promoting their photosynthetic production. Watt \& McGregor (1963) found that second-year needle length was increased by first-year prolonged photoperiod treatment in four northern conifers seedlings. This disagreed with our results on leaf length in CYS, unless COS was added, suggesting that $\operatorname{COS}$ addition affects the growth of current tissues in seedlings subjected to extended photoperiod. Hansen \& Beck (1994) reported that oligosaccharides decreased drastically in Scots pine (Pinus sylvestris L.) trees in spring, when new tissues were intensively growing. This evidence supports the possible function of exogenous $\operatorname{COS}$ as a modifier of needle growth.

The promotion of current biomass accumulation in Buddhist pine seedlings subjected to extended photoperiod has been reported (Wei et al. 2013, Zhu et al. 2016b). Such effect persists over the second-year regardless COS addition; indeed, first-year stem biomass accounted for about $60 \%$ of second-year biomass in Buddhist pine seedlings, and first-year stem was the only organ with greater biomass accumulation under the longer photoperiod without $\mathrm{COS}$ addition in the second year. However, when $\cos$ was added biomass for all organs was increased in the extended photoperiod treatment. According to previous analysis, the increase of biomass in CYS mainly resulted from the elongation of current leaves. Contrastingly, no effect of COS addition was found on the number of new roots in Buddhist pine seedlings.

Both $\mathrm{N}$ and $\mathrm{P}$ concentrations in shoots treated with $\mathrm{COS}$ declined in seedlings subjected to extended photoperiod, revealing the symptom of nutrient dilution. Generally, nutrient dilution tends to happen in fall, when seedling growth continued during hardening without sufficient nutrient supply, which could lead to the degradation of seedling quality and lowered posttransplant performances (Andivia et al. 2014). Therefore, nutrient dilution in shoots may be considered as a serious drawback caused by the exposure of seedlings to the extended photoperiod. However, shoot $N$ and $\mathrm{P}$ concentrations in our study seemed to be acceptable for transplanted seedling growth, as nutrients were utilized for biomass accumulation and leaf elongation in CYS (Fig. 4). It is worthy to notice that only with COS addition nutrient concentration was diluted in seedling shoots. These results, along with those about growth and biomass accumulation in CYS, suggest that first-year COS addition promoted the utilization of $N$ and $P$ in shoots for CYS growth. On the other hand, the longer photoperiod induced higher $\mathrm{N}$ concentration in annual organs, but less $\mathrm{P}$ retained in roots (Tab. 2). This finding is the opposite of that reported by Wei et al. (2013), in oneyear-old Buddhist pine seedlings, where $\mathrm{N}$ concentration was lower and $\mathrm{P}$ concentration was higher in annual organs under the longer photoperiod. In the first year a large amount of $\mathrm{N}$ was allocated to shoots and roots for utilization, while most $\mathrm{P}$ was retained in annual organs. Nevertheless, the $\mathrm{N}$ demand by CYS was not so compelling under the extended photoperiod in the second year as a large amount of $\mathrm{N}$ was retained in the roots.

In seedling treated with $\operatorname{COS}$, we found both lower $\mathrm{N}$ concentration in roots and greater $\mathrm{N}$ content in first-year shoots, which could be caused by two separated processes. The decline of $\mathrm{N}$ concentration in roots was driven by the $\mathrm{N}$ utilization for CYS growth in response to COS addition, because of both CYS growth and increase of shoot $\mathrm{N}$ concentration in COS-treated seedlings. On the other hand, the greater $\mathrm{N}$ content observed in the old stem of seedlings likely resulted from biomass ac- 
cumulation therein, as nutrient content is the result of nutrient concentration by biomass. In contrast, the higher $\mathrm{P}$ content in old stems after COS addition was mainly attributed to the promotion of $\mathrm{P}$ concentration, but it did not lead to biomass accumulation. Further, with the addition of COS $P$ uptake and accumulation was found to be enhanced in all seedling organs. COS addition had also been found to promote $P$ uptake in Maize (Zea mays - Suganya et al. 2015) and coffee (Coffea canephora var. Robusta - Dzung et al. 2011).

\section{Conclusions}

Current understanding of the effect of $\mathrm{COS}$ on plants was mainly based on studies on herbaceous plants, and few information exists on woody species. In the present study, a two-year experiment was conducted on Buddhist pine seedlings treated with $\operatorname{COS}$ addition under contrasting photoperiods. Under the extended photoperiod $\operatorname{COS}$ addition increased leaf length in $\mathrm{CYS}$ as well as biomass accumulation and $\mathrm{N}$ content at the whole-plant scale. In contrast, addition of COS decreased RCD under the natural photoperiod treatment, but it had no effect on seedling height. Both $\mathrm{N}$ and $\mathrm{P}$ concentrations in seedling shoots were increased by COS addition under the extended photoperiod, and they were also negatively correlated with leaf length and biomass accumulation in CYS.

In conclusion, the effect of extended photoperiod on growth and nutrient utilization would diminish in CYS of transplanted Buddhist pine seedlings, unless $\operatorname{COS}$ was added during culture. Both seed coating and leaf spraying with $\operatorname{COS}$ were found to result in similar effects on plant growth.

This study is the first trial to determine the over-year effect of COS on tree seedlings under contrasting photoperiods. Additional studies on different tree species are needed to confirm our results and avoid possible species-specific limits of this study.

\section{Acknowledgments}

This study was supported by the National Natural Science Foundation of China (31600496) and The National Key Research and Development Program of China (2016YFC0500307).

\section{References}

Andivia E, Fernández M, Vázquez-Piqué J (2014). Assessing the effect of late-season fertilization on Holm oak plant quality: insights from morpho-nutritional characterizations and water relations parameters. New Forests 45: 149-163. - doi: 10.1007/s11056-013-9397-1

Apostol KG, Dumroese RK, Pinto JR, Davis AS (2015). Response of conifer species from three latitudinal populations to light spectra generated by light-emitting diodes and high-pressure sodium lamps. Canadian Journal of Forest Research 45: 1711-1719. - doi: 10.1139/cjfr-2015-0106 Augspurger CK (2009). Spring 2007 warmth and frost: phenology, damage and refoliation in a temperate deciduous forest. Functional Ecology 23: 1031-1039. - doi: 10.1111/j.1365-2435.2009. 01587.x

Barigah TS, Saugier B, Mousseau M, Guittet J, Ceulemans R (1994). Photosynthesis, leaf area and productivity of five poplar clones during their establishment year. Annals of Forest Science 51: 613-625. - doi: 10.1051/forest:19940607 Bumgarner ML, Salifu KF, Mickelbart MV, Jacobs DF (2015). Effects of fertilization on media chemistry and Quercus rubra seedling development under subirrigation. Hortscience 50: 454460. [online] URL: http://hortsci.ashspublicat ions.org/content/50/3/454.short

Chatelain PG, Pintado ME, Vasconcelos MW (2013). Evaluation of chitooligosaccharide application on mineral accumulation and plant growth in Phaseolus vulgaris. Plant Science. 215216: 134-140. - doi: 10.1016/j.plantsci.2013.11.009 Dzung NA, Khanh VTP, Dzung TT (2011). Research on impact of chitosan oligomers on biophysical characteristics, growth, development and drought resistance of coffee. Carbohydrate Polymers 84: 751-755. - doi: 10.1016/j.carb pol.2010.07.066

Fetene M, Feleke Y (2001). Growth and photosynthesis of seedlings of four tree species from a dry tropical afromontane forest. Journal of Tropical Ecology 17: 269-283. - doi: 10.1017/So2 66467401001183

Fernandez M, Marcos C, Tapias R, Ruiz F, Lopez $G$ (2007). Nursery fertilization affects the frosttolerance and plant quality of Eucalyptus globulus Labill. cuttings. Annals of Forest Science 64: 865-873. - doi: 10.1051/forest:2007071

Garner WW, Allard HA (1923). Further studies in photoperiodism, the response of the plant to relative length of day and night. Journal of Agricultural Research 23: 871-920. [online] URL: http://naldc.nal.usda.gov/download/IND43966 624/PDF

González A, Castro J, Vera J, Moenne A (2013). Seaweed oligosaccharides stimulate plant growth by enhancing carbon and nitrogen assimilation, basal metabolism, and cell division. Journal of Plant Growth Regulation 32: 443-448. - doi: 10.1007/s00344-012-9309-1

Gu LH, Hanson PJ, Post WM, Kaiser DP, Yang B, Nemani R, Pallardy SG, Meyers T (2008). The 2007 Eastern US spring freeze: increased cold damage in a warming world? Bioscience 58 : 253-262. - doi: 10.1641/B580311

Hawkins BJ, Henry G (1999). Nutrition and bud removal affect biomass and nutrient allocation in Douglas-fir and western red cedar. Tree Physiology 19: 197-203. - doi: 10.1093/treephys/19.3. 197

Hansen J, Beck E (1994). Seasonal-changes in the utilization and turnover of assimilation products in 8-year-old scots pine (Pinus sylvestris L.) trees. Trees - Structure and Function 8: 172-182. doi: $10.1007 /$ BFo0196844

Hussain I, Singh T, Chittenden C (2012). Preparation of chitosan oligomers and characterization: their antifungal activities and decay resistance. Holzforschung 66: 119-125. - doi: 10.1515/ HF.2011.130

Jia XC, Meng QS, Zeng $\mathrm{HH}$, Wang WX, Yin $\mathrm{H}$ (2016). Chitosan oligosaccharide induces resistance to Tobacco mosaic virus in Arabidopsis via the salicylic acid-mediated signaling pathway. Scientific Reports. 6: 26144. - doi: 10.1038/ srep 26144

Kollárová K, Zelko I, Henselová M, Capek P, Lišková D (2012). Growth and anatomical parameters of adventitious roots foremed on mung bean hypocotyles are correlated with galactoglucomannan oligosaccharides structure. Scientific World Journal 2012: 797815. - doi: 10.1100 /2012/797815

Li SJ, Zhu TH (2013). Biochemical response and induced resistance against anthracnose ( $\mathrm{Col}$ letotrichum camelliae) of camellia (Camellia pitardii) by chitosan oligosaccharide application. Forest Pathology 43: 67-76. - doi: 10.1111/j.14390329.2012.00797.x

Millard P, Grelet GA (2010). Nitrogen storage and remobilization by trees: ecophysiological relevance in a changing world. Tree Physiology 30: 1083-1095. - doi: 10.1093/treephys/tpq042

Nambiar EKS, Fife DN (1991). Nutrient retranslocation in temperate conifers. Tree Physiology 9 (1-2): 185-207. - doi: 10.1093/treephys/9.1-2.185 Oliet JA, Tejada M, Salifu KF, Collazos A, Jacobs DF (2009). Performance and nutrient dynamics of holm oak (Quercus ilex L.) seedlings in relation to nursery nutrient loading and post-transplant fertility. European Journal of Forest Research 128: 253-263. - doi: 10.1007/s10342-0090261-y

Oliet JA, Salazar JM, Villar R, Robredo E, Valladares $F$ (2011). Fall fertilization of Holm oak affects $\mathrm{N}$ and $\mathrm{P}$ dynamics, root growth potential, and post-planting phenology and growth. Annals of Forest Science 68: 647-656. - doi: 10.1007/s13595-011-0060-8

Pokharel P, Chang SX (2016). Exponential fertilization promotes seedling growth by increasing nitrogen retranslocation in trembling aspen planted for oil sands reclamation. Forest Ecology and Management 372: 35-43. - doi: 10.1016/j. foreco.2016.03.034

Riikonen J, Kettunen N, Grisevich M, Hakala T, Sarkka L, Tahvonen R (2016). Growth and development of Norway spruce and Scots pine seedlings under different light spectra. Environmental and Experimental Botany 121: 112-120. doi: 10.1016/j.envexpbot.2015.06.006

Seyoum Y, Fetene M, Strobl S, Beck E (2014). Daily and seasonal courses of gas exchange and niche partitioning among coexisting tree species in a tropical montane forest. Flora Morphology, Distribution, Functional Ecology of Plants 209: 191-200. - doi: 10.1016/j.flora.2014. 02.005

Silkina OV, Vinokurova RI (2009). Seasonal dynamics of chlorophyll and microelement content in developing conifer needles of Abies sibirica and Picea abies. Russian Journal of Plant Physiology 56: 780-786. - doi: 10.1134/S10214437 09060077

Suganya V, Nagajothi R, Jeyakumar P (2015). Nod factor (Lipo Chito-oligosaccharide) and its impact on nutrient uptake in maize (Zea mays). International Journal of Tropical Agriculture 33: 125-129. [online] URL: http://www.cabdirect.org /cabdirect/abstract/20153325897

Villar-Salvador P, Uscola M, Jacobs DF (2015). The role of stored carbohydrate and nitrogen in the growth and stress tolerance of planted forest trees. New Forests 46: 813-839. - doi: 
10.1007/s11056-015-9499-z

Watt RF, McGregor WHD (1963). Growth of four northern conifers under long and natural photoperiods in Florida and Wisconsin. Forest Science 9: 115-128. [online] URL: http://www. ingentaconnect.com/content/saf/fs/1963/0000 0009/00000001/artoo023

Wang MY, Chen YC, Zhang R, Wang WX, Zhao $X M$, Du YG, Yin H (2015). Effects of chitosan oligosaccharides on the yield components and production quality of different wheat cultivars (Triticum aestivum L.) in Northwest China. Field
Crop Research 172: 11-20. - doi: 10.1016/j.fcr.2014. 12.007

Wei HX, Ren J, Zhou JH (2013). Effect of exponential fertilization on growth and nutritional status in Buddhist pine (Podocarpus macrophyllus [Thunb.] D. Don) seedlings cultured in natural and prolonged photoperiods. Soil Science and Plant Nutrition 59: 933-941. - doi: 10.1080/ 00380768.2013 .864957

Zhu KY, Liu HC, Wei HX, Zhou JH, Zou QC, Ma GY, Zhang JQ (2016a). Prediction of nutrient leaching from culture of containerized Buddhist pine and Japanese maple seedlings exposed to extended photoperiod. International Journal of Agriculture and Biology 18: 425-434. - doi: 10.17957/IJAB/15.0108

Zhu KY, Liu HC, Zhou JH, Zou QC, Ma GY, Zhang JQ, Wei HX (2016b). Growth, nutrient uptake and utilization of Buddhist pine and Japanese seedlings to the extended photoperiod. Journal of Zhejiang University (Agriculture and Life Sciences) 42: 190-198. - doi: 10.3785/j.issn.10089209.2015.04.081 